\title{
JNPH
}

Volume 7 No. 2 (Oktober 2019)

(C) The Author(s) 2019

\section{EFEKTIVITAS TERAPI BERMAIN ASSOSIATIF TERHADAP KEMAMPUAN MOTORIK PADA ANAK AUTIS}

\author{
EFFECTIVENESS OF ASSOCIATIVE PLAYING THERAPY ON MOTOR \\ SKILLS IN AUTISM CHILDREN \\ SISKA ISKANDAR, INDARYANI \\ PROGRAM STUDI DIII KEPERAWATAN AKKES SAPTA BAKTI BENGKULU \\ Email: siska.flonfel@gmail.com
}

\begin{abstract}
ABSTRAK
Autis merupakan salah satu gangguan perkembangan pervasif (GPP) dan termasuk dalam kelainan spectrum autis atau ASD Autistic Spectrum Disorder salah satunya adalah gangguan fungdi motorik. Terapi bermain assosiatif merupakan salah satu intervensi yang dapat diberikan dalam melatih kemampuan motorik anak autis. Penelitian ini bertujuan untuk mengetahui efektivitas terapi bermain asosiatif terhadap peningkatan kemampuan motorik pada anak autis menggunakan metode penelitian survey analitik dengan pendekatan kuasi eksperimen yang mana anak dibagi menjadi 3 kelompok kecil dan melakukan permainan asosiatif. Penilaian kemampuan motorik dilakukan sebelum diberikan terapi bermain dan diobservasi selama terapi diberikan. Hasil penelitian menunjukkan rata-rata kemampuan motorik sebelum dilakukan terapi bermain assosiatif pada anak autis adalah 0,00 dengan standar deviasi 0,00. Setelah dilakukan terapi bermain assosiatif pada anak autis didapatkan rata-rata kemampuan motorik adalah 1,67 dengan standar deviasi 0,50. Hasil uji statistik didapatkan nilai $\mathrm{p}$ value adalah 0,000 sehingga dapat terlihat adanya perbedaan yang signifikan antara kemampuan motorik sebelum dilakukan terapi bermain assosiatif dan setelah dilakukan terapi bermain assosiatif pada anak autis. Dari hasil penelitian tersebut dapat disimpulkan bahwa terapi bermain assosiatif efektif dalam meningkatkan kemampuan motorik pada anak autis sehingga disarankan kepada sekolah pendidikan khusus untuk memasukkan terapi bermain dalam kurikulum pendidikan sekolahnya.
\end{abstract}

\section{Kata Kunci : Terapi Bermain Assosiatif, Autis, Kemampuan Motorik}

\begin{abstract}
Autism is a pervasive developmental disorder (GPP) and is included in the autism spectrum disorder or ASD Autistic Spectrum Disorder, one of which is motor dysfunction. Associative play therapy is one of the interventions that can be given in practicing motor skills in children with autism. This study aims to determine the effectiveness of associative play therapy for increasing motor skills in children with autism using analytic survey research methods with a quasi-experimental approach in which children are divided into 3 small groups and play associative games. Assessment of motor skills is carried out before play therapy is given and observed during therapy. The results showed the average motor ability before playing associative play therapy in children with autism was 0.00 with a standard deviation of 0.00 .
\end{abstract}


After conducting associative play therapy in children with autism, the average motor ability is 1.67 with a standard deviation of 0.50 . The statistical test results obtained $p$ value is 0,000 so that it can be seen that there are significant differences between motor skills before associative play therapy and after associative play therapy in children with autism. From these results it can be concluded that associative play therapy is effective in increasing motor skills in children with autism so it is suggested to special education schools to include play therapy in their school education curriculum.

\section{Key Word : Associative Playing Therapy, Autism, Motor Skills}

\section{PENDAHULUAN}

Autisme adalah ketidakmampuan perkembangan yang ditandai dengan gangguan pada wicara dan bahasa, mobilitas, dan hubungan interpersonal. Ini merupakan gangguan perkembangan pervasif (GPP) dan termasuk dalam kelainan spectrum autis atau ASD (Autistic Spectrum Disorde) (Prasetyono, 2008). Kelainan ini sering didiagnosis pada umur 18 sampai 30 bulan. Ketika itu, orang tua atau dokter baru menyadari setelah ada keterlambatan bicara yang disertai oleh gangguan perilaku dan interaksi sosial (Soetjiningsih, 2013).

Perkembangan motorik merupakan faktor yang sangat penting dalam menjalankan aktifitas fisik sehari-hari. Perkembangan motorik berkaitan dengan otot-otot yang membutuhkan koordinasi mata, tangan dan kaki. Menurut Hasnita (2015), hampir semua anak autis mengalami permasalahan dalam motorik halus, gerak gerik kaku dan kasar, anak autis sering terlihat kesulitan untuk memegang, menekan, menggenggam dan menjimpit benda. Gangguan motorik tersebut tidak bersifat permanen, kemampuan motorik pada anak autis dapat dikembangkan melalui kegiatan melatih kekuatan otot dan koordinasi otot-otot kecil yang kontinue secara rutin (Santrock, 2011).

Selama kurun waktu 10 tahun terakhir ini, masalah autis meningkat pesat di seluruh dunia. Data UNESCO tahun 2011, terdapat 35 juta orang penyandang autis dengan rata-rata 6 dari 1000 orang dunia mengalami autis. Menurut Pusat Pengendalian dan Pencegahan Penyakit Amerika Serikat tahun 2012, terjadi peningkatan yang cukup memprihatinkan dengan jumlah rasio 1: 88 anak. Di Indonesia, tahun 2015 tercatat sebanyak 656 anak menderita autis (Soetjingsih, 2013). Di Provinsi Bengkulu, terdapat 119 yang terdiagnosa autis pada 4 klinik terapi autis, yang terdiri dari klinik Lasipala sebanyak 26 anak, PK-PLK Mutiara Bunda sebanyak 32 anak, Autis centre sebanyak 30 anak, dan RSJ sebanyak 31 anak

Berdasarkan permasalahan tersebut maka perlu suatu cara untuk mengembangkan kemampuan motorik anak autis sesuai dengan karakteristik anak tersebut. Terapi yang efektif digunakan untuk meningkatkan kemampuan motorik adalah terapi bermain yang bekerja pada anak-anak dengan cara mengembangkan keterampilan-keterampilan baru yang disukai oleh anak itu sendiri (Juneja, 2016). Bermain merupakan salah satu kebutuhan penting abgi anak. Dengan bermain anak dapat belajar untuk beradaptasi, bersosialisasi serta bebas berekspresi.

Permainan memiliki peran penting dalam mengembangkan dan memperhalus berbagai kemampuan gerak dasar, jika permainan secara tepat dimainkan ke dalam program pengembangan gerak. Menurut Gunarsa (2008) beberapa permainan dan alat permainan sederhana dapat mengembangkan aspek motorik anak. Menurut Raharjo (2014) dengan bermain otot-otot anak akan bekerja maksimal, metabolisme tubuh meningkat dan perkembangan otot lebih bagus. Dalam bermain, anak autis dapat mencakup perkembangan lainnya.

Salah satu terapi bermain yang digunakan adalah terapi bermain assosiatif menggunakan plastisin dan karton gambar. 
Permainan ini termasuk mainan edukasi yang membantu gerak motorik anak agar berkembang dengan baik serta merangsang daya imajinasi dan kreativitas anak. Bermain assosiatif merupakan suatu aktivitas bermain yang sama tetapi masih belum terorganisir, tidak ada pembagian tugas, mereka bermain sesuai keinginannya sehingga anak autis dapat mengikuti terapi dengan gembira tanpa ada aturanyang mengikat (Riyadi, 2012).

Sesuai dengan fungsi utama bermain yaitu merangsang perkembangan sensorikmotorik, perkembangan sosial, perkembangan kreativitas, perkembangan kesadaran diri, perkembangan moral dan bermain sebagai terapi (Ambarwati \& Nita, 2012), peneliti tertarik melakukan penelitian menggunakan alat permaianan plastisin dan karton gambar dalam merangsang perkembangan kemampuan motorik anak autis. Adapun tujuan dalam penelitian ini adalah mengetahui efektifitas terapi bermain assosiatif dalam meningkatkan kemampuan motorik pada anak autis.

\section{METODE PENELITIAN}

Penelitian ini menggunakan metode penelitian survey analitik dengan pendekatan kuasi eksperimen yang mana anak dibagi menjadi 3 kelompok kecil dan melakukan permainan asosiatif. Penilaian kemampuan motorik dilakukan sebelum diberikan terapi bermain dan diobservasi selama terapi diberikan. Analisa data dilakukan untuk melihat efektivitas terapi bermain dengan menggunakan analisis statistik baik secara univariat untuk melihat distribusi frekuensi maupun bivariat dengan menggunakan $U j i$ Paired-Samples T Test.

\section{HASIL PENELITIAN}

Penelitian ini dilakukan selama 1 bulan dengan 12 kali pelaksanaan terapi bermain. Alat permainan yang digunakan adalah plastisin dan karton gambar dimana anak dibagi menjadi 3 kelompok dan setiap kelompok terdiri dari 3 orang anak. Hal ini sesuai dengan pendapat Chusairi (2012), bahwa Terapi bermain sosial dapat memberikan hasil yang efektif apabila dilakukan secara terus menerus dan berkelanjutan, serta dilakukan dalam kelompok kecil (maksimal 6 orang).

Tabel 1. Distribusi Frekuensi Kemampuan Motorik Pada Anak Autis Sebelum dan Sesudah Dilakukan Terapi Bermain

\begin{tabular}{ccc}
\hline Kriteria & $\begin{array}{c}\text { Sebelum Terapi } \\
\text { Bermain (\%) }\end{array}$ & $\begin{array}{c}\text { Setelah Terapi } \\
\text { Bermain (\%) }\end{array}$ \\
\hline Baik & 42 & 75 \\
Kurang Baik & 58 & 25 \\
\hline Jumlah & 100 & 100 \\
\hline
\end{tabular}

Pada Tabel 1.didapatkan adanya peningkatan kemampuan motorik pada anak autis sebelum dilakukan terapi bermain palstisin dan karton gambar (58\%) kurang baik dan setelah dilakukan terapi bermain $(75 \%)$ baik. Hal tersebut dapat dilihat dari perilaku anak dalam bermain antara lain melakukan gerakan sesuai dengan aturan permainan dan tidak melakukan gerakan yang berulang-ulang.

Tabel 2. Distribusi Rata-Rata Kemampuan Motorik Melalui Terapi Bermain Pada Anak Autis

\begin{tabular}{|c|c|c|c|c|c|}
\hline Variabel & Mean & SD & $\mathrm{SE}$ & $\begin{array}{c}\mathrm{P} \\
\text { value }\end{array}$ & $\mathrm{N}$ \\
\hline \multicolumn{6}{|l|}{ Kemampuan Motorik } \\
\hline Sebelum terapi & 0,00 & 0,00 & 0,00 &, 000 & 9 \\
\hline bermain & 1,67 & 0,50 & 0,17 & & \\
\hline $\begin{array}{l}\text { Setelah terapi } \\
\text { bermain }\end{array}$ & & & & & \\
\hline
\end{tabular}

Tabel 2. menunjukkan adanya peningkatan rata-rata kemampuan motorik anak autis sebelum dilakukan terapi bermain $(0,00)$ dan setelah dilakukan terapi bermain $(1,67)$ dengan nilai $\mathrm{p}$ value $=0,000$ yang berarti adanya hubungan yang signifikan antara terapi bermain dengan kemampuan motorik pada anak autis. 


\section{PEMBAHASAN}

Berdasarkan hasil penelitian dapat diketahui adanya perbedaan yang signifikan antara kemampuan anak autis sebelum dilakukan terapi bermain assosiatif dengan setelah dilakukan terapi bermain assosiatif menggunakan plastisin dan karton gambar. Hal ini sejalan dengan penelitian yang dilakukan oleh Wardah (2017) menemukan bahwa bermain menggunakan playdough berpengaruh terhadap kemampuan motorik halus anak autis di SDLBN Tompokersan Lumanjang yang dibuktikan dengan pengujian dua sisi $(\mathrm{Zh}>\mathrm{Zt})$ berarti ada pengaruh signifikan dari bermain playdough terhadap kemampuan motorik halus anak autis. Menurut Putri (2017), ada hubungan antara terapi dengan pertumbuhan dan perkembangan anak autis. Terapi bermain pada anak menggunakan berbagai macam alat permainan. Permainan sederhana dapat menstimulasi perkembangan anak apabila dilakukan secara rutin.

Perkembangan motorik terdiri dari motorik kasar dan motorik halus. Motorik kasar adalah kemampuan anak dalam melakukan gerakan yang melibatkan bagianbagian tubuh tertentu dan dilakukan oleh otototot besar yang merupakan area terbesar pada masa perkembangan, diawali dengan kemampuan berjalan, kemudian berlari, lompat dan lempar. Motorik halus adalah kemampuan anak dalam melakukan gerakan yang melibatkan bagian-bagian tubuh tertentu dan dilakukan oleh otot-otot kecil, tetapi memerlukan koordinasi yang cermat seperti mengamati, menjipit dan menulis. Pada anak autis mengalami kelemahan otot-otot motorik tertentu sehingga dengan melakukan terapi bermain secara rutin dapat melatih kemampuan motorik tersebut (Handojo, 2003).

Penelitian yang telah dilakukan oleh Wiyono (2014) mengenai pengaruh permainan terhadap kemampuan motorik kasar anak autis menemukan bahwa ada pengaruh signifikan penggunaan permainan engklek terhadap kemampuan motorik kasar anak autis di sekolah mutiara hati siderejo. Sedangkan Raharjo (2014) menyatakan bahwa terdapat perbedaan perkembangan motorik halus anak autis sebelum dan setelah terapi bermain menggunting di sekolah luar biasa negeri semarang yang mana berdasarkan hasil uji Wilcoxon, positif rank menunjukkan bahwa terdapat 24 anak yang mengalami peningkatan dari motorik halus kurang baik dan setelah dilakukan terapi bermain, respon motorik halusnya menjadi baik.

Kurnianingsih (2017), menemukan bahwa perkembangan motorik halus pada anak autis harus sering dilatih atau diasah supaya anak mengalami peningkatan dalam perkembangan motorik halus. Perkembangan motorik halus ini membutuhkan daya konsentrasi yang baik maka harus dilatih setiap hari dan anak juga membutuhkan motivasi dari keluarga dalam melakukan tindakan yang dapat meningkatkan kemampuan motorik halus.

\section{KESIMPULAN}

Kesimpulan dari penelitian ini adalah ada perbedaan yang signifikan antara kemampuan motorik pada anak autis sebelum dilakukan terapi bermain dan setelah dilakukan terapi bermain. Terapi bermain assosiatif sangat efektif dalam meningkatkan kemampuan motorik anak autis

\section{SARAN}

Hasil Penelitian ini diharapkan dapat menjadi referensi bagi peneliti selanjutnya. Untuk institusi pendidikan anak berkebutuhan khusus dapat menggunakan terapi bermain assosiatif menggunakan plastisin-karton gambar dalam membantu proses pembelajaran guna peningkatan kemampuan motorik pada anak berkebutuhan khusus terutama anak autis

\section{DAFTAR PUSTAKA}

Ambarwati \& Nita. 2012. Buku Pintar 
Asuhan Keperawatan Bayi dan Balita.

Yogyakarta : Cakrawala Ilmu

Chusairi, Achmad., Hamidah, Tino Leonardi. 2012. Efektivitas terapi bermain sosial untuk meningkatkan kemampuan dan keterampilan sosial bagi anak dengan gangguan autism. Jurnal Ilmiah. http://Journal.unair.ac.id.

Gunarsa, Singgih D dan Yulia Singgih D. 2014. Psikologi Perkembangan anak dan Remaja. Jakarta: PT. BPK Gunung Muliya.

Handojo, Y. 2003. Autisma: Petunjuk Ptaktis dan Pedoman Materi Untuk Mengajar Anak Normal, Autis dan Perilaku Lain. Jakarta :

Hasnita, Evi. dkk. 2015. Terapi Okupasi Perkembangan Motorik Halus Anak Autism. Jurnal Ipteks Terapan Research Of Applied Science And Education V9.I1 (20-27). http://doi.org/10.22216/jit.2015.v9i1.25

Juneja, A. 2016. Therapeutic Role of Play Therapy: A Review. IJSR-International Journal Of Scientific Research. Volume:5 (10) 291-292.

Kurnianingsih, Rizki Putri dan Dera Alfiyanti. 2017. Perkembangan Motorik Halus Pada Anak Autis Berdasarkan Kategori Anak Autis, Usia, dan Jenis Kelamin (Studi Observasi Pada Siswa Sekolah Luar Biasa Negeri Semarang). Stike Telogorejo Semarang.

Prasetyono,Ds. 2008. Serba Serbi Anak Autis. Yogyakarta: Diva Press.

Putri, kristy Mellya. 2017. Hubungan Terapi Bermain Dengan Pertumbuhan dan Perkembangan Pada Anak Autis. Menara Ilmi Vol XI Jilid 2 No 78 November 2017. ISSN 1693-2617.

Raharjo, Desta S. 2014. Pengaruh Terapi Bermain Menggunting Terhadap Peningkatan Motorik Halus Anak Autis Usia 11-15 Tahun Di Sekolah Luar Biasa Negeri Semarang Jurnal Ilmu Keperawatan dan Kebidanan Vol 3.

Riyadi, Sujono. Dan Sukarmin. 2012. Asuhan Keperawatan Pada Anak. Yogyakarta: Penerbit Graha Ilmu.
Santrock, John W. 2011. Perkembangan Anak Edisi 7 Jilid 2. Jakarta: Erlangga.

Soetjiningsih. 2013. Tumbuh Kembang Anak Edisi 2. Jakarta: Penerbit Buku Kedokteran EGC.

Speer. 2007. Recana Asuhan Perawatan Pediatrik dengan Klinikal Pathways. Jakarta : Penerbit Buku Kedokteran EGC.

Wardah, Erika Yunia dan Madechan. 2017. Bermain Playdough Terhadap kemampuan Motorik Halus Anak Autis Di $S D L B$. Universitas Negeri Surabaya. 